\title{
THEORETICAL ASSUMPTIONS TO THE DESIGN OF THE NATIONAL LOGISTICS SUPPORT SYSTEM
}

\author{
Mirosław Chaberek ${ }^{\mathrm{a}}$, Cezary Mańkowski ${ }^{\mathrm{b}}$ \\ ${ }^{\mathrm{a}, \mathrm{b}}$ University of Gdańsk, Gdańsk, Poland \\ ae-mail: ekomc@ug.edu.pl \\ be-mail: ekocm@ug.edu.pl
}

\begin{abstract}
Purpose: The purpose of this article is to formulate theoretical assumptions to the design of the national logistics support system at the model form according to the logistics needs of the national economy.

Methodology: The methodology approach includes such methods as holism, modelling and logical reasoning, which are supported by such research tools as system, model, induction, reduction, deduction.

Findings: The research results are presented at the macro-model of servicing the country recourses' requirements by the national logistics system. The structure of the system is hierarchical, composed of three level and three logistics subsystems of macroeconomic model of the national economy, macro-model of the logistics service of the country economy, and operational model of logistics chains.

Originality/value: The proposed set of theoretical assumptions formulated at the form of the national logistics support system model, fill the literature gap on macrologistics system on a country level.
\end{abstract}

Keywords: macrologistics, assumptions, model

Paper type: Research paper

\section{Introduction}

The construction of a national logistics support system is necessary to build a competitive advantage of national economy, which results will be used not only by companies of logistics services sector, but also by the other business and non-business organisations. The rationale for creating such a project is the multitude of factors, which determine its design and functioning in practice. There are numerous external and internal conditions of political, social, economic, technology, legal, and environment provenience, which heavily influence the macrologistics system. 
THEORETICAL ASSUMPTIONS TO THE DESIGN

Mirosław Chaberek Cezary Mańkowski
Currently, there has been known no methodology that would allow a comprehensive, holistic analysis of the aforementioned conditions to design the national logistics support system. Existing solutions of a similar nature have got fragmentary and selective dimensions, which mean that they are not reliable tools in the long-term planning of logistics structural investments and activities within the system. Therefore, there is a need for a research, which would provide an answer to the question, what a logistics system does a national economy require? To find the answer to the above question, a set of theoretical assumptions to build this system should be formulated first, for instance at the form of an idea, conception, or a model. Thus, the research problem for this paper is what the theoretical assumptions should be, or speaking more detailed, how the logistics systems should looks like, what components it should consist of, what real and regulatory functions it should perform? This problem determines the aim of this research and this paper as well, which can be stated as to formulate theoretical assumptions to the design of the national logistics support system. This aim is carried out by a research process, which starts with the literature review, then the analysis of the supporting, integration and regulation nature of logistics systems is performed to formulate theoretical assumptions at the form of a conceptual model of the proposed national logistics system finally.

Therefore, the expected research result, as well as the contribution to the state of art, is the theoretical model of servicing the national economy's requirements by the logistics system. The structure of the system is intended to be hierarchical, composed of three levels and three subsystems:

- macroeconomic model of the national eceonomy,

- macro-model of the logistics service of the country economy,

- operational model of logistics chains.

Because the model is formulated on a relatively high level of abstract, it has got a generic nature and falls into the class of macrologistics theoretical (conceptual) models.

\section{Research methodology}

Due to the aim of this research to develop the conceptual assumptions for the project of the national logistics support system, the general methodology approach is a holism with its main category of a holon at the sense of a system as a whole and at the same time as a part of a higher level system (Gammelgaard, 2004). This methodological approach implies that the proposed set of theoretical assumptions will be hierarchical and related to each other.

For the system design purposes the method of modelling is used with its main tool of model as a simplified picture of a real or a proposed object, which at this case is a model of proposed macrologistics system at its conceptual phase, which can be modified, extended, specified at the next phases, and applied finally. To 
construct the conceptual model a block scheme drawing method is applied to reflect the structure of the modelled system.

The above mentioned methodology is supported by standard scientific methods at the form of the literature critique review and heuristic analysis of the studied literature materials. For the purpose of this article professional books and articles, focused on the researched problem, have been examined. Within the whole research process the methods of reduction, induction and deduction have been applied to ensure the course of reasoning to be logical and free of meritoric errors.

The results of the research process are included at two chapters followed by discussion and conclusion. The first chapter presents the theoretical background and identifies literature gap on the macrologistics systems, at which perspective the content of this article takes an original character and contributes to the state of art. The second chapter includes some notes on the supportive role of the logistics system in relation to so called primary processes. In addition to the integration and regulatory features of the logistics systems, a set of theoretical assumptions are formulated, which are abstracted at the graphical structure of the national logistics support system.

\section{Literature review}

Literature study proves that probably every logistics publication touches the problem of logistics system, its elements or element. The general problem on logistics system definition, its classification and structure at different aspects, points of view or levels have been researched and published widely at the literature (Pfohl, 2018; Blaik, 2010), therefore there is no need to repeat them at this article. Instead of it, the detailed perspective of the national logistics system is put as the right object of a literature review.

The national logistics support system should be classified according to the literature as a macrologistics system, which is usually defined “(...) as a part of the economy and deals with the design of general economic flow systems. By means of laws, institutions and the creation of an optimal infrastructure, macrologistics should enable efficient flow of information and transportation flows. Macro-logistics is not at the focus of business considerations." (Bücher and Sezer, 2003). Similar perception of the macrologistics system is expressed at the next definition, according to which it can be seen "(...) as a whole of physical and information flows occurring in supply chains, whose links are entities operating within the economy of a given country (national macrologistics), the European continent (eurologistics), and even the whole world (world economy macrologistics, or global logistics) (...)" (Skowrońska, 2013). Taking a critical review to the above presented definitions it can be stated that the macrologistics system can be understood as a subsystem of a national economy (the first
THEORETICAL ASSUMPTIONS TO THE DESIGN

Mirosław Chaberek Cezary Mańkowski 
THEORETICAL ASSUMPTIONS TO THE DESIGN

Mirosław Chaberek Cezary Mańkowski definition) as well as a system of national economy (the second definition) at the same time, under the assumption that there are no other flows but information and real ones at supply chains and economies, what makes them equal at this perspective. Not only is the relation to the economy system discussable. The main activity, process or functional scope of the macrologistics system can also be put under the critique. For instance, the flow designing function is stressed at the first definition, while the physical and information flow is underlined at the second definition, what is in contradiction to the first one, similar as a subject to the object of designing. In addition, these definitions do not express explicitly, what is the main purpose of the macrologistics system, they only implicitly indicate on designing, creation or enabling real flows, what rises a questions if the real flows are also a part of macrologistics systems, because designing, creation or enabling are rather regulatory activities, not real? Some other misunderstandings are created by opinions, which maintain that "A systematic approach for identifying the opportunities for macrologistics changes and using them to gain corporate competitive advantage is called macrologistics system." (Stein and Voehl, 1998), because according to this definition, macrologistics system is functioning on a corporate level, what is in contradiction to the national level, which macrologistics systems are usually designed for. Fortunately, there are also authors (Banomyong et al., 2008), who see the difference between macro and regional logistics systems.

Looking for the other publications, which could provide more in-depth study results to the above presented considerations a working paper on national logistics systems by Dimitrov (1991) is worthy to review first. This publication was probably the first comprehensive research on national logistics systems in six Western countries (UK, Sweden, The Netherlands, Japan, Finland, USA) and six Eastern countries (Bulgaria, Czechoslovakia, Hungary, Poland, Yugoslavia, GDR). Despite the data included at the report are outdated, because they reflect the national logistics systems of the above mentioned countries at the years of 1970-1988, so at the times of a central planned economy in the case of Poland, some issues are valuable to be pointed out. First one is the definition of national economy, which is understood " $(. .$.$) as material flows and stock system, which$ involves numerous material flows and points (economic units) of inventory formation" (Dimitrov, 1991), and which seems to be more related to the definition of national logistics system than the economy system, however it underlines the important role of logistics in the country's economy. Secondly, each of the twelve national logistics systems was analysed at two aspects, this is as a physical system and as an administration system. This theoretical assumption taken to the logistics is still important and actual; because it makes clear that the logistics not only a regulatory, managerial, coordination or integration system, but also it is a real one, especially at the form of transportation and inventory, what is sometimes 
questioned even up today. The similar approach to conceptualise the national logistics system can be found at the publications of D. Kisperska-Moron (1996) and M. Jacyna (2012). The first author proposes to perceive the system as a set of production, trade, non-production and individual customers sectors of national economy, linked and integrated by transportation and information processes, while the proposition of the second author can be treated as the continuation of the previous conception, but more detailed, because the model consists of five kinds of output and input points, connected by transhipment points, transportation and information processes. Both propositions are very good reflection of the real national logistics system as a self-managing, non-hierarchical systems, which existed at that time. However, nowadays, in addition to the above discussion on the macrologistic system, its structure and relations to the economy system, especially from the point of view, which maintains that macrologistics systems are not at the focus of business considerations, but for instance economic policy one (Bücher and Sezer, 2003), the most problematic issue seems to be the question, what a subject has got, or should be given, the power to manage the macrologistics system (including the above mentioned activities of designing, creation, enabling), and what managerial implication does it cause? Theoretical as well as empirical researches' results are highly insufficient, because there are very few publications on this problem. At this perspective, it is worthy to mention the work of A. Skowrońska (2009), where she indicated on the state logistics policy as the right body to implement the national sustainable development. The other example is a case study done by Havenga J. (2018), who analised some elements of South Africa macrologistics system, especially at logistics cost perspective, with a suggestion about a need for "(...) a national strategic vision for South Africa's freight logistics industry to support sustainable economic development" (Havenga, 2018). In line with this suggestion is the proposition of Tavasszy and De Jong (2014), who perceive transport and logistics as an element of public policy with an influence on the national competitiveness. All the above mentioned studies indicate on the state or public unit as the responsible subject designed for macrologistics system, especially on national level. However, none of these studies formulate a holistic conception of macrologistics system, including national one. Because a research task to develop a full conception exceeds the frame of one article, the theoretical assumptions to design a national logistics system are formulated at first.

\section{Theoretical approach to design a national logistics support system}

A foundation for every theoretical conception or practical application regarding logistics system is constituted by an unquestionable paradigm, which maintains that every economic process of trade, production or service character requires logistics system, which provides the process with the right resources (human,
THEORETICAL ASSUMPTIONS TO THE DESIGN

Mirosław Chaberek Cezary Mańkowski 
THEORETICAL ASSUMPTIONS TO THE DESIGN

Mirosław Chaberek Cezary Mańkowski material, financial and information), in the right amount, delivered at the right place, time and cost (5R) (Chaberek, 2014; Chaberek and Mańkowski, 2017).

Developing the idea included at the above paradigm, it should be stated first that talking about logistics in general, or more detailed about logistics system and process, can only be done at the sense of a service system to another economic system, which is primary in relation to the logistics one. Primary, because primary needs have to be born together with the way of satisfying them through the production, trade or service processes, which at this perspective can be called as primary processes. The intention to perform these primary processes determines what right resources are required for them, at what quantity, place, time, conditions etc. It means also that the term "right" is possible to be identified and fully measurable, for instance at the form of such logistics indicators as the volume, lead time, logistics service quality etc. Speaking other words, if there is no primary process, which requires to be supported with resources, there is also no need for logistics system. That is the primary process, which determines the scope of required logistics services.

Beside the service or support function, the integration function of the logistics support system is also important. The integration function can be compared to the role of interfaces, external as well internal to create synergy effects (Szmelter, 2013). External ones, they are between the primary process, logistics process and the processes of other involved parties, for instance financial or insurance companies. Internal ones, they include relations to their own subsystems. Especially, the level of integration between the primary and logistics system is important, because it decides about the competitiveness of the whole supply chain. It is worth to mentioned, that this relation is undergoing market changes. For instance, the development of new logistic systems can be observed at the form of logistics orchestrator, which takes the responsibility for integrating and coordinating a wide range of business activities, both primary and supporting, including physical logistics activities offered for instance by so called "third party logistics" operators.

The two above mentioned service and integration functions of logistics are appropriate for the all kinds of logistics support systems, however, if they are to be performed on a national level, which refers to the smooth flow of resources between companies, towns, regions, and other organisations within a country, a third aspect, called as a regulatory one, is required. Therefore, particularly for the national logistics support systems, some regulatory assumptions should be proposed. Usually, the regulatory tools are identified with legislative regulations; however they can be also social, economic, or technological means, which can be used to achieve the state level and country range of the resources flow integration. Especially, at the aspect of the perspective Polish national support system, it is necessary to state that there is no national logistics support system and, what 
is worse, Poland does not have a national strategy for the development of such a system, which takes advantages and opportunities of geographical location of the country. Although, there are several government programs and plans, as for instance a strategy for responsible development until 2020 with a perspective up to 2023, a master plan for rail transport in Poland until 2030, or such investment plans as Via Carpathia, Rail Baltica, Central Communication Port, etc., however no program, which could be perceived as the main regulatory tool, which would present the entire logistics concept of the country, has not been developed yet. From regulatory point of view, this program should tackle with some modern problems, above all on interoperability, co-modality, inter-connectivity, physical internet, internet of things, omni-channeling, traceability and visibility of supply chains, as well as it should include propositions how to resolve existing problems with technical standardisation or notification of norms and regulations. Of course, there is still open the question about a subject, which should been given a power to regulate the Polish logistics support system.

With the aim to give some answers to the above raised problems and questions, the following conceptual propositions to design the national logistics support system are formulated. Based on the previously mentioned assumption that every logistics system serves the primary process at the required resources, the first task to design such a system is to get information on the resource needs of the country at the real time for traceability purposes and of course with a possibility to make simulations for the future map of these needs. It is worthy to say that this task or function is not only the first one but also of ultimate importance, because the quality of received data on the country resources needs are crucial for the macrologistics decisions. At the second stage, the macroeconomic data are proposed to be used as the input to design the model of logistics flows within the country, including trans-border flows. Then the logistics model is suggested to be detailed into the operational resource flow model, which would consist of supply chain maps reflecting the required flows details. A graphical design of the entire system is presented at the Figure 1, according to which a three-level system, which constitutes also three subsystems, is proposed.

Speaking more detailed, the proposed model of the national logistics support system is intended to be a hierarchical set of three sub-models. However, not to leave the model as a naive one the following specification of the model is added. Research methods to meet design assumptions are planned to be provided by cybernetics, econometrics, statistics and IT at this model. In the field of cybernetics, first of all the anticipatory structure of the model and controlling algorithm of monitoring parameters changes, based on the identification of variances outside the confidence interval, should allow to obtain a historical, current and perspective picture of the country economy dynamics and logistic tasks resulting from them. Next, the comparison between the planned and real 
THEORETICAL ASSUMPTIONS TO THE DESIGN

Mirosław Chaberek Cezary Mańkowski

Figure 1. The structure of the national logistics support system

Source: own elaboration. date ensure to calibrate the accuracy of the system, while additional computer algorithms will ensure the automation of this calibration. As it was said before, the most important element of this model and at the same time the most difficult task is the estimation of the national economy recourses' needs. This task is suggested to perform with the application of econometric models, most likely recursive, wavelet equations, informatically recorded in the form of self-learning neural networks, and designed to describe the dynamics of the economy and forecast the resources needs for logistics services. Due to the service role of logistics in relation to the national economy, the macro-model of the logistics service and the operational model of logistics chains will have a resultant character in relation to the macroeconomic model, because logistic services change accordingly to the dynamics of the country economy. Therefore, the methodological basis for the structure of the logistics macro-model the Sankey scheme at the IT form together with the procedure of its service is suggested. The flow diagram of Sankey will in turn provide input data to the operational logistics model (level three of the method). This model is intended to consist of four components:

1) generation of logistics tasks, which will be absorbed in logistics chains;

2) spatial motion map - a transport matrix within logistics chains;

3) breakdown of logistics tasks, which allow to define requirements for logistics resources;

4) map of traffic network to determine the movement path or paths between selected spatial points.

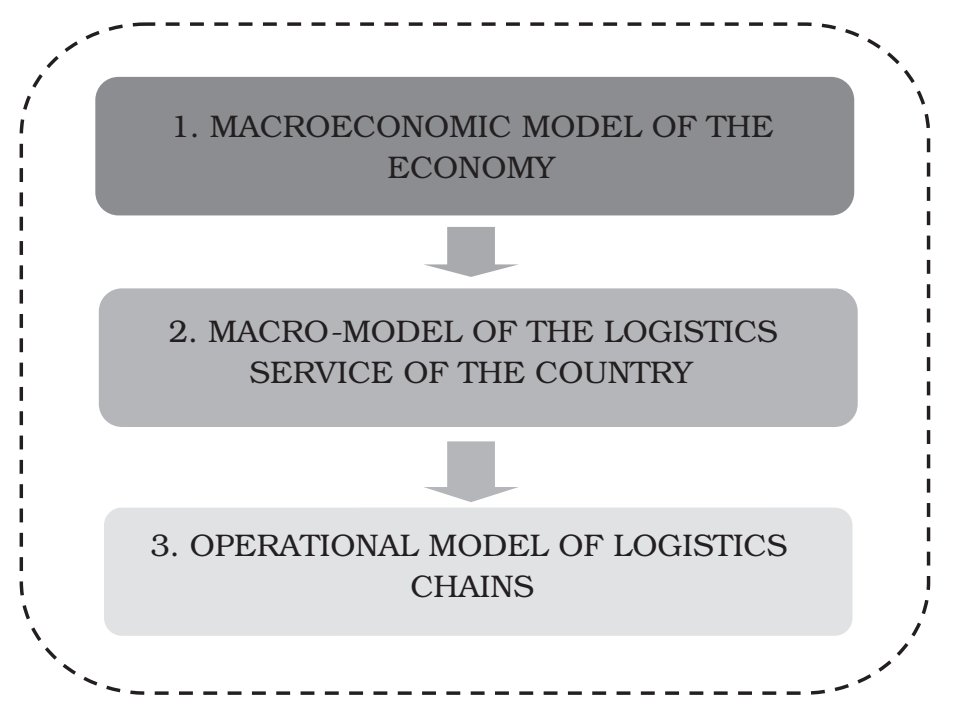




\section{Discussion}

The above presented conceptual outline of the national logistics support system together with its design stages indicate on the possibility to obtain the following results at the form of:

1) a holistic vision of the national logistics support system's functions and structure;

2) a practical application, which includes a hierarchical dynamic model, covering three levels of the system;

3) a tool for efficient management of the national logistics support system;

4) a tool for implementing the economic policy of strategic development corresponding to national and EU requirements;

5) a tool, which allows to simulate economic scenarios and defining the national logistics support system, in the case of macroeconomic variables' changes;

6) a product and process innovation, at least on the national scale, in the form of the above-mentioned model, with the possibility of using it in the long-term perspective, among others thanks to the built-in functions of self-learning and the continuous adaptation.

In comparison to the other propositions presented at this article it seems that the model included at the Figure 1 is more comprehensive than the others. For instance, it contains a macroeconomic model, which includes not only the requirements of the economy, which are directed into the logistics services, buy also is planned to reflect real economic ties at the form of input-output tables. Similarly, the third sub-model, called operational model of logistics chains is planned to be a kind of national traffic model, which could provide, if designed correctly, very detailed information on the objects of flows, the line and point infrastructure used, the transportation means engaged, including their parameters. Additionally, this proposition has also got some managerial implications, because macrologistics decisions based on this model, and taken for instance on investments in the national transportation network, can influence managers of construction companies, logistic operators, consignors and consignees of goods, and other interested parts as for their decisions on the cargo routes, freight rates, modernisation of transportation fleet etc. Therefore, this model is general at its conceptual layer, but very substantial at its methodological and meritoric aspect. Thus, it requires a further application at the form of specification and implementation.

\section{Conclusion}

Designing process of the national logistic support system should begin with the identification and analysis of the current state of elements of this system, taking into account their mutual relations. That is the reason why it is suggested 
THEORETICAL ASSUMPTIONS TO THE DESIGN

Mirosław Chaberek Cezary Mańkowski first to build a macroeconomic model of the country's economy to estimate its requirements for resources. Then a macro-model of logistics services is proposed to transpose the resources needs into a map of logistics flows. And finally to trace the flows within supply chains, an operational subsystem should be designed to reflect the detailed data. Of course, the proposed theoretical model is designed on a very high level of abstract; however it seems to be just the right level for designing macrologistics systems. It contributes to the existing propositions through offering to macroeconomic and managerial (decision) purposes a hierarchical, but still comprehensive approach to design macro, as well as, operational logistics flows. Because the proposition is formulated at a high level conception form, the limitation lies at its generality; however the content of the model specified at the chapter four reveals some details and indicate at the same time the direction for the further researches, especially at the form of application works.

\section{References}

Banomyong, R., Cook, P., Kent, P. (2008), "Formulating regional logistics development policy: The case of ASEAN", International Journal of Logistics Research \& Applications, Vol. 11 No. 5, pp. 359-379. DOI: 10.1080/13675560802389114

Blaik, P. (2010), Logistyka. Koncepcja zintegrowanego zarzadzania, Polskie Wydawcnitwo Ekonomiczne, Warszawa.

Bücher, J., Sezer, M. (2003), Alternative Lösungsansätze für die Distributionslogistik am Beispiel des Onlinelebensmitteleinzelhandels, LIT Verlag, Münster.

Chaberek, M. (2014), "Theoretical, Regulatory and Practical Implications of Logistics", LogForum, Vol. 10 No. 1, pp. 3-12.

Chaberek, M., Mańkowski, C. (2017), "Teleological assumptions in the process of identification and evaluation of best logistics practices", Research Journal of the University of Gdańsk, Transport Economics and Logistics, Vol. 71, pp. 7-16. DOI: 10.5604/01.3001.0010.5720

Dimitrov, P. (1991), "National Logistics Systems", Collaborative paper CP-91-006, IIASA, Laxenburg, Austria, available at: http://pure.iiasa.ac.at/id/eprint/3574/ (accessed 16 May 2019), pp. 4-33.

Gammelgaard, B. (2004), "Schools in logistics research? A methodological framework for analysis of the discipline", International Journal of Physical Distribution \& Logistics Management, Vol. 34 No. 6, pp. 480-481. DOI: 10.1108/09600030410548541

Havenga, J.H. (2018), "Logistics and the future: The rise of macrologistics", Journal of Transport and Supply Chain Management, Vol. 12, pp. 4-6. DOI: 10.4102/jtscm. v12i0.336

Jacyna, M. (Ed.) (2012), System logistyczny Polski. Uwarunkowania techniczno-technologiczne komodalności transportu, Oficyna Wydawnicza Politechniki Warszawskiej, Warszawa.

Kisperska-Moroń, D. (1996), System logistyczny gospodarki polskiej, Akademia Ekonomiczna w Katowicach, Katowice. 
Pfohl, Ch.H. (2009), Logistiksysteme. Betriebswirtschaftliche Grundlagen, Springer Verlag, Berlin Heidelberg.

Skowrońska, A. (2009), Rola polityki logistycznej państwa we wdrażaniu zrównoważonego rozwoju, Wydawnictwo Uniwersytetu Ekonomicznego, Wrocław.

Skowrońska, A. (2013), "Makrologistyka w polityce Unii Europejskiej”, Gospodarka Materiałowa i Logistyka, Vol. 4, s. 2-9.

Stein, M., Voehl, F. (1998), Macrologistics Management: A Catalyst for Organizational Change, CRC Press, Boca Raton, Florida.

Szmelter, A. (2013), Synergy phenomenon in supply logistics, Lambert Academic Pub., Saarbrucken, pp. 8-90.

Tavasszy, L., Jong, G. (2013), “Introduction”, in: Tavasszy, L., Jong, G. (Eds.), Modelling freight transport, Elsevier, Amsterdam, pp. 1-12. 